\title{
Students' Perception on Entrepreneurship Education: The Case of Universiti Malaysia Perlis
}

\author{
Teh Yi Nian ${ }^{1}$, Rosni Bakar ${ }^{1} \&$ Md. Aminul Islam ${ }^{1}$ \\ ${ }^{1}$ School of Business Innovation and Technopreneurship, Universiti Malaysia Perlis, Malaysia \\ Correspondence: Md. Aminul Islam, School of Business Innovation and Technopreneurship, Universiti Malaysia \\ Perlis, Malaysia. E-mail: amin@unimap.edu.my
}

Received: June 4, 2014 Accepted: August 13, 2014 Online Published: September 23, 2014

doi:10.5539/ies.v7n10p40 URL: http://dx.doi.org/10.5539/ies.v7n10p40

\begin{abstract}
Entrepreneurship education plays an important role in developing entrepreneurs. The entrepreneurship knowledge and skills have vital contribution to economic growth. This study aims to investigate the practice of entrepreneurship education in University Malaysia Perlis and perception of students on entrepreneurship education. Primary data are collected to reveal students' perceptions toward entrepreneurship education, for example the teaching method and their desired entrepreneurship skills. The results show that the performance of entrepreneurship education in University Malaysia Perlis was favorable and recognized by students. The results also include the preferred teaching method and assessment methods of students. The findings of this study will contribute to the further research in the area of entrepreneurship education and provide useful information for higher learning institutions in Malaysia to improve their entrepreneurship education curricula and practices.
\end{abstract}

Keywords: entrepreneurship, entrepreneurship education, students' perception, teaching methods, assessment method

\section{Introduction}

The increasing importance of entrepreneurship education and its ability to contribute to economic growth and job opportunities have inspired many universities to offer entrepreneurship education subjects both in academic and non-academic programs. Although there are an increasing number of students who are taking entrepreneurship education, the ability to hone entrepreneurship value with traditional teaching methods remains unclear and its possibility remains debatable. During mid-1990s, the emergence of knowledge based economy in Malaysia had cause knowledge to become main resource in most of the economic activities (Cheng, Chan, \& Mahmood, 2009). This phenomenon is the reason for the increasing demand for entrepreneurship education in Malaysia. Although many scholars such as Klein and Drucker support that entrepreneurship can be taught and learn, the effectiveness of the entrepreneurship education still remain to be unseen. Method of teaching entrepreneurship education and learning style of students are important factors to determine the effectiveness of entrepreneurship education. Not all students able to follow one particular way of teaching since different students have their own different ways of learning. The success of a learning methods differ from student to student and the result of one teaching method of a student to the next is not the same.

There are wide variety of teaching methods that could be used to teach entrepreneurship to students from the traditional approach such as creation of business plans or tutorials to the interactive methods such as case studies and guest speakers. Traditional teaching method and style might able to teach the students about the knowledge of entrepreneurship and business strategies to success but it unable to develop the critical characteristic of entrepreneurs such as creativity and need for autonomy among the students.

Solomon (2007) had conducted a research to examine the entrepreneurship education in United States. He found that the most popular teaching method in universities of United States was the development of business plans, class discussions and guest speakers. The results show that traditional teaching method like creation of business plan still remains popular in United States. It also shows that education institutions are shifting toward a knowledge sharing pedagogical as class discussion and guest speakers are becoming more popular.

Students claimed that they need to focus more on the theories that are used in exam while the practical sides of entrepreneurships such as problem solving and decision making were less developed and this became one of the 
factors that caused the ineffectiveness of entrepreneurship education in the Malaysia (Cheng, Chan, \& Mahmood, 2009). According to Felder and Brent (2005), students are different from one another because each student has their own preferred learning style and their learning pace. Each student has their own characteristics and abilities to determine the type of lesson they could respond with their best, how they approach their studies, and their attitude toward the nature of knowledge (Felder \& Brent, 2005). Since there are so many different teaching methods for entrepreneurship education, there is a need to revise the methods used to improve entrepreneurship education. Prior to the discussion of the earlier issues regarding entrepreneurship education, there is an urgent need to study the entrepreneurship education in higher learning institutions in Malaysia. The study therefore attempted: (i) to identify the entrepreneur education provided in higher learning institute, (ii) to identify the preferred teaching method in entrepreneurship education courses (iii) to identify the preferred assessment methods in entrepreneurship education courses; and (iv) to identify desired skills and acquired skills of students in entrepreneurship education.

\subsection{The Importance of Entrepreneurship Education}

Entrepreneurship is one of the main factors to improve the economic in a country as it able to create wealth for the entrepreneurs. The ability to create job, reduce the unemployment and create economic boom are among the main reasons why many countries are fostering and realizing the importance of entrepreneurship education (Importance of Entrepreneurship Education, 2004). The creations of new business ventures by entrepreneurs generate jobs opportunities and help stimulate the economy and drive new industry of the country. McMullan (1988) emphasize the importance of entrepreneurship education to economic development and view it as one of the important element of the community support infrastructure (cited by Lekoko, 2012 from McMullan, 1988). The Global Entrepreneurship Monitor (GEM) found that most of the entrepreneurs began their career because they were left out and unemployed during the global recession (Bosma \& Levie, 2010). Furthermore, many starting entrepreneurs felt that there are many opportunities to start their business in the recession. But the reality is, many of these entrepreneurs fail in their business are due to the lack of entrepreneurship knowledge, skills and attitudes that are required to prosper in business during economic crisis. Many entrepreneurs face challenges not because of the lack of opportunities and resources but because they don't have the required skills and business sense.

Entrepreneurship education is therefore, is to prepare graduates to be successful in their career when they set up a new business venture or in small medium enterprise (SME). Innovation is one of the most important element to acquire when students learn about entrepreneurship education. Innovation will support them to stand out from other competitors with unique ideas and set up an SME successfully. In many industrial countries, some studies show that the SMEs play an important role in contribution to the economic and social life, as well as its ability to increase GDP and creates of jobs in the countries.

Figure 1 shows the gross domestic product (GDP) and small medium enterprise (SME) growth in Malaysia between 2001 and 2010. SMEs contribute total of 32\% shares of GDP in 2010 which increase $3.4 \%$ from $28.6 \%$ shares of GDP in 2004. SME growth is totally outperformed overall GDP growth during 2004-2010(Makip, 2012).

\section{GDP \& SME Growth}

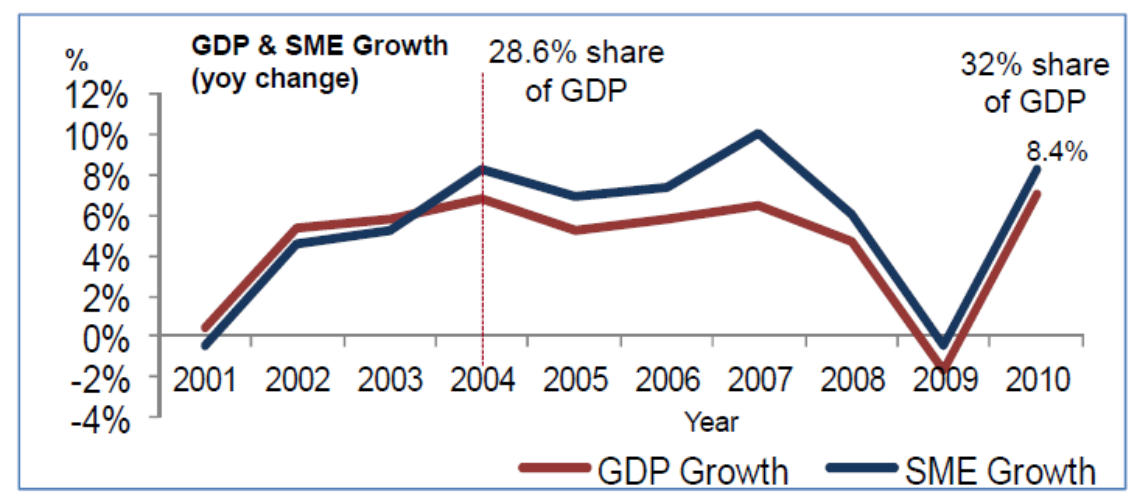

Figure 1. The GDP\&SME growth in Malaysia. (Source: DOSM and SME Corp. Malaysia) 


\subsection{The Global Presence of Entrepreneurship Education}

The global presence of entrepreneurship education must be discussed in order to fully understand the importance of entrepreneurship educations in institutions of higher learning. Entrepreneurship is widely recognized in United States as approximately 5.6 million Americans under age 34 are attempting to start their own business ventures (cited by Kuratko, 2005 from Tulgan, 1999). Interestingly, it is found that one third of new entrepreneurs is younger than 30 years old, more than $60 \%$ of $18-29$ years old youngster say they want to have their own business ventures and almost $80 \%$ of entrepreneurs in the United States are between the ages 18 years old and 34 years old (Kuratko, 2005 from Tulgan, 1999).The increasing demand of entrepreneurship had driven the massive growth of entrepreneurship education in United States. The first entrepreneurship course was introduced and offered at Harvard University in 1947. Since then, more universities start to offer the entrepreneurship course and numerous courses relate with entrepreneurial activities has been introduced in United States.

According to Garavan and O'Cinneide (1994), the major challenges of entrepreneurship education is the appropriate curricula and training programs for teaching entrepreneurship knowledge and skills (Garavan \& O'Cinneide, 1994). This gives the rise to the question "can the entrepreneurship be taught?" Experts in entrepreneurship education believe that it can be taught and entrepreneurs are made, not born. Klein (2006) states that some of entrepreneurship skills and knowledge can be taught and some cannot be. He mentions that the increasing of recognition of entrepreneurship specialist and economist toward each other will lead to more consistent approaches to the teaching of entrepreneurship (Klein, 2006). Peter Drucker, one of the world leading management thinker and leader of management education state that, the entrepreneurial is not a magic or mysterious and it has nothing to do with genes. Entrepreneurship is a discipline, and like any other discipline, it can be learned (Kuratko, 2004).

The entrepreneurship education in United States helps in motivating other countries around the world to start the entrepreneurship education. United Kingdom focuses greatly on the building of entrepreneurship in their society. Kirby found that most of the British universities have listed business and entrepreneurial development as one of the four major strategies goals in their universities (Adcroft et al., 2005). This shows that entrepreneurship education do have the important impact on the economy and society to the country. The same phenomenon is happening in Malaysia. During 1990, Malaysia started to invested effort to transform their economy from agriculture based economy to knowledge based economy. The rise of knowledge based economy is the main factor that increases the development of entrepreneurs in Malaysia (Cheng, Chan, \& Mahmood, 2009). The implementation of knowledge based economy has driven education institution like colleges and universities to implement steps to contribute to the development of entrepreneurial talent among young graduates. Thus the entrepreneurship education starts to be introduced in many universities in Malaysia.

\section{Literature Review}

Entrepreneurship is defined as a dynamic process of creating incremental wealth by entrepreneurs who take responsibility for the major risks in terms of equity, time and career commitment (Hisrich, Michael, \& Shephard, 2005). Entrepreneurship include few behaviors such as (1) initiative taking, (2) organizing and reorganizing social and economic mechanisms to turn resources and situation to practical account, (3) the acceptance of risk or failure(Hisrich, Michael, \& Shephard, 2005). Gartner (1985) described the creation of a new venture via four different dimensions: (1) individual(s), (2) process, (3) environment and (4) organization (Gartner, 1985). Individual(s) state the personalities of the entrepreneurs such as need of achievement, locus of control and risk taking propensity in new venture creation. The process mentions about common behaviors of the entrepreneurships including locate a business opportunities and accumulating resources. Environment refers as externalities of conditions that organization needs to be adapted. Additionally, another perspective which sees environment as a reality that organization creates based on perception has been developed as well. Lastly, the organization element relates the characteristics of the organization to the competitive strategies like entry wedges and joint ventures.

\subsection{Entrepreneurship Education}

Entrepreneurship education or also known as entrepreneurial education is used to deliver entrepreneurial knowledge, skills and abilities to the students for helping them to success their career as an entrepreneur. Entrepreneurship education train the student to gain innovative enterprise skills and capture the opportunities to success in business venture. Bechard and Toulouse (1998) define entrepreneurship education as a teaching process that provide information, training and educates anyone that interest in entrepreneurial activities (cited by Jones \& English, 2004 from Bechard \&Toulouse, 1998).Entrepreneurship education is different from business 
education. Vesper and McMullen (1988) pointed out that one of the main objective of entrepreneurship education that differentiates it from typical business education is to generate more quickly a greater variety of different ideas for how to exploit a business opportunity, and the ability to project a more extensive sequence of actions for entering business (cited by Solomon, 2007 from Vesper \& McMullen, 1998). Gartner and Vesper (1994) states that, business entry is completely different activity compare to business management (cited by Solomon, 2007 from Gartner \& Vesper, 1994).

\subsection{Entrepreneurship Education Research in Few Countries}

This section reviews the past research about entrepreneurship education in some countries. A study about the effectiveness of entrepreneurship education at University Icesi, Cali, Colombia had been carried out by Varela and Romero (2009). They measured the proportion of entrepreneurship alumni by finding out what are the proportion of alumni that started their own business in the condition and the characteristic of their business. This research was divided into two stages. Two methods were used in the first stage which one of it is the internet questionnaire that developed to a number of 2504 alumni. A total of 670 samples of questionnaires were received in the first stages. At the second stage, a more detailed questionnaire that was applied in personal interviews to the actual entrepreneurs only in order to characterize their companies and get additional information about the new entrepreneurial support activities. The results show that there are significant difference among the percentages of alumni that choose to become entrepreneurs and those who choose to work for another. Although students from different programs take the entrepreneurial subject but the students from business administration program are more likely to become entrepreneurs while no entrepreneur came from the system engineering programs. The entrepreneurship courses and extracurricular activities do helped the alumni in starting their business ventures and succeed it. Thus the efforts of the Center of Entrepreneurship Development (CDEE) in university were well recognized and appreciate by the Alumni.

For Indonesia, Abduh (2012) found that the entrepreneurship education in the Bengkulu University is growing overtime as more students want to become entrepreneurs and wish to take the entrepreneurship education for their choice of study. Most of the knowledge provided in the entrepreneurship education are important for students especially business plan, financial planning and financial report. Students are more satisfied with the innovative teaching method such as entrepreneurship lecturers, class discussion, individual and group task but not satisfied with the traditional teaching method like self-directed learning and individual tasks in preparing a business plan. Moreover, students have a high expectation to the abilities they learned through entrepreneurship program. Majority of participants experienced difficulties in understanding the entrepreneurship programs and the teaching methods among the lecturers are vary from different faculty in term of materials and teaching methods. The findings show the importance of the teaching methods and subject material for helping student in understanding the entrepreneurship education programs. These teaching methods and subject materials need to be further improved and develop new teaching methods in order to support students to understand the entrepreneurship.

Cheng, Chan, and Mahmood (2009) conducted a study about the effectiveness of entrepreneurship education in Malaysia. They used the questionnaire as survey instrument to collect the students' perception of the effectiveness of the entrepreneurship education. Respondents were selected from five different higher education institutions, 300 respondents were selected to complete the self-administrated questionnaires and 90 respondents were selected to complete the pilot questionnaires. The study shows that the effectiveness of entrepreneurship education in Malaysia still remain low as there was still many different between students' skills expectations with their skills acquisitions. Moreover, the result shows that the level of understanding on "what is entrepreneurship" still remain slow among the respondents in this study. Cheng (2009) conclude that, educational institutions in Malaysia should review the existing curriculum to find the problems that cause the ineffectiveness of the entrepreneurship education. In the same times, the education institution should focus on design a better curriculum to increase the effectiveness of the entrepreneurship education. Only with an effective entrepreneurship education, then students will become a successful entrepreneurs that could face the challenge in today's global economy.

Chan (2005) conducted a study of entrepreneurship education in Australia. She used the Australian university website to obtain the data about the undergraduate and postgraduate degrees in entrepreneurship education for thirty eight universities in Australia. PEST analysis (Political, Economic, Social and Technological environment) was used to analyze the entrepreneurship education in Australia. In the research, Chan found that most of the entrepreneur programs and units offered by Australian Universities were not different from other academic programs in terms of teaching delivery methods, curricula, facilities, advertising and promotion. The entrepreneurship education in Australia mainly study the theories and model on marketing, finance, management, 
develop business plan and gaining access and insight from real entrepreneurs.

Solomon (2007) had carried a study to examine the entrepreneurship education in United States. His study chooses the online questionnaires as the research instrument. The study shows that the rapid growth of technologies has improve the study of entrepreneurship educations. The online information helped the students to search the data at a faster rate and time saving. The study also showed that the education institutions are shifting the teaching method toward a more knowledge sharing ecology method such as guest speaker and group discussion.

However, a study in Singapore suggests that problem based-learning (PBL) approach could be an effective approach for entrepreneurship education. In the study, Tan and $\mathrm{Ng}$ (2006) used the case study method that monitored and documented the performance of a pioneer batch of students who took up the entrepreneurship programs. During the discussion, they explored two issues in the implementation problem-based learning (PBL) approach to entrepreneurship education which are: i) how PBL emphasize the knowledge application over content acquisition and provide knowledge to student during the entrepreneurial process and ii) how PBL reflect real-world problems, facilitate more meaningful entrepreneurial-training. As the result, problem-based learning (PBL) approaches able to emphasis the learning process through solving "real-world" problems as well as the multi-solution approach. Problem-based learning (PBL) will help to develop the critical thinking, ability to think cross-functionally and ambiguity tolerance inside the students. These skills are important and desirable that required by entrepreneurs in order to success their careers.

\section{Research Methodology}

The quantitative data had been collected using the questionnaire survey instrument. A close-end surveys were piloted for the first questionnaire and total of 10 questionnaire has been distribute to 10 students to gain the response and comment on the questionnaires constructed. After the pilot test, a new questionnaire survey has been carried out after the reconstruction on the piloted questionnaire based on the comment and the response that gained during the pilot test. Questionnaire has been chosen as the survey instrument to examine the entrepreneurship education provided in university. The main reason for choosing questionnaire as survey instrument is the flexibility of the questionnaire. Questionnaire can be designed differently to meet the objectives of the research (McNabb, 2008). The length of questionnaire can be long or short, the question can be simple or complex and straightforward branched. These make the questionnaire to become flexible and easier to conduct and tabulate when come to data finding. Questionnaire can be designed to determine what people know, what they think, or how they act or plan to act (McNabb, 2008). They can measure subject's factual knowledge about a thing or a number, people's opinions, frequencies and prediction future actions in certain way (McNabb, 2008). Another popular method mention in last section is interview or known as in-person data collecting methods. This survey instrument can provide rich information and get better data by having interaction with the respondent (McNabb, 2008). Interaction with the respondent will help them to understand more about the question or topic discussed and gather large amount of information easily. Although in-person data collecting method has a lot of advantages and it certainly surpass questionnaire in term of data and information collection, but the time needed to conduct this survey are much more longer compare to the questionnaire survey. Besides, the cost for this survey instrument is high and it might be the most costly method among all survey instrument (McNabb, 2008). Since the limitations in this survey include cost and length of time, thus questionnaire survey methods fit the most in this study as it was more suitable and easier to conduct.

The questionnaire has divided into 3 sections: In Section A, students were asked about their details with their identity remain confidential and coded. The respondents only require to state in the details of gender, nationality, ethnic group, current year of study and the faculty. In Section B, students were asked about the self-attitudinal questions and questions about the perception of participant toward entrepreneurship education. The factors and motivation that encourage participant to involve in entrepreneurial activities and opinions about entrepreneurial will be asked. In Section $\mathrm{C}$, students were asked about the question that asking participant about the entrepreneurship education in UniMAP. It includes the questions that could reflect their opinion toward entrepreneurship education in UniMAP and preferred teaching method will be mentioned in the questions.

A pilot study is a small scale methodological test that uses to test the proposed methods and procedures can perform in practice before being applied in a large and expensive investigation (Chaudhary, 1991). A set of questionnaires were constructed after finished review the past research in the literature review. After that, a pilot test has been conducted to test the validity of the questionnaires. After pilot test was conducted, the comment and responses toward questionnaire will be obtained. These comment and responses could help to edit the current questionnaire to become better and more suitable for the research. After that, the data gained will key in into 
Statistical Package for Social Science (SPSS) to analyze the validity and the reliability of the questionnaire. The questions that show low validity or low reliability will be removed and reconstruction for the questionnaire will be carried out until the questionnaire show valid and reliable. This survey is using a simple random sampling method to collect the data. This study focus on the students who already took entrepreneurs subject EUW 224 Engineering Entrepreneurship to examine the entrepreneurship education in UniMAP. Since UniMAP designed this subject as a compulsory subject that must be taken by all students regardless the students are from schools of engineering or school of business, it is hard to determine the population of the students that already took the subject. Therefore in this research, 200 random students that completed the subject EUW 224 were targeted as the population of this study. A total number of 131 set of questionnaire had been distributed and 124 set was returned. Among the 124 set questionnaire, only 120 set had shown valid and been analyzed.

\section{Findings}

131 sets of questionnaires had been distributed personally. During the process, only 124 set of questionnaire (94.7\%) was received. Among 124 sets of questionnaire, only 120 sets of questionnaire were satisfactorily completed and tested by the Statistical Package for Social Science (SPSS) software. The reason for the decrease of questionnaire might be due to the respondents incorrectly answering the section or is duplicated results that are deemed invalid. It shows that there are $36.7 \%$ of male respondents and $63.3 \%$ of female respondents in this study. The majority of the respondents for this study are Malaysian (96.7\%) and only some of respondents are from China (3.3\%). $44.2 \%$ of the respondents are Chinese while $36.7 \%$ of the respondents are Malay and the remaining $15 \%$ are Indian. The minority $4.2 \%$ are other ethnic group including Kenyah, Sabah Bumiputera and Iban. There are $3.3 \%$ of respondents in this study that are listed as international ethnic group. From Table 4.2, $87.5 \%$ of respondents are third year students while $10.8 \%$ are second year students and only $1.7 \%$ are fourth year students. There are $74.2 \%$ of respondents come from School of Business Innovation and Technopreneurship while $25.8 \%$ of respondents come from Schools of Engineering that include School of Computer \& Communication Engineering, School of Electrical System and School of Microelectronic Engineering.

The respondents are required to rate the regularity of teaching methods used in delivering entrepreneurship education in UniMAP based on their own judgment of given scale. The results show that lectures (mean=3.4) is still the most regular teaching method that was used to deliver entrepreneurship education in UniMAP while the second often used teaching method in entrepreneurship education is case studies (mean=2.9). The rest of teaching methods are entrepreneurs' talk/guest speaker (mean=2.8), companies visit/interviewing entrepreneurs (mean=2.5), business simulation (mean=2.5), involvement in business competition (mean=2.3) and multimedia exercise (mean $=2.2$ ).

Respondents were then asked to rank a number of attitudinal statements based on a Likert scale ranging of 1 to 5 where 1 is the most important. Result shows that most of the respondents in UniMAP prefer a steady income stream and want to be their own boss (both mean=2.8). Followed by respondents who like to take risk (mean=2.9) and prefer creativity of new idea (mean=3.0). There are only few of the respondents prefer to led by other leaders (mean=3.1). However, it also shows that most of the students are urged to succeed and gain wealth rather than being independent and have flexibility of times. This result might lead to an assumption that students are being too realistic and materialistic nowadays.

Questions whether students' would like have own business after graduation, there are total of $85.8 \%$ of respondents expressed that they are interested in starting their own business in the future. $84.3 \%$ of respondents from School of Business wanted to start their own business venture and $90.3 \%$ of respondents from Schools of Engineering are interested in starting their business in future as well. This might become evidence that entrepreneurship education in UniMAP is able to influence engineering students on their intention to start their own business. Further investigation is needed to examine this phenomenon. Respondents were asked to rate factors that influence them on entrepreneurial interest in starting their own business in the future. Those respondents who are interested in starting their own business are most significantly influenced by their own interest (mean=1.6). Family influence is the next factor that influence them to start their own business $(m e a n=2.4)$. Followed by high profile entrepreneurs $(m e a n=2.9)$, Friends (mean=3.2), Media $(m e a n=4.0)$ and University programs (mean=4.1). The seventh place "Other" influences $($ mean=6.8) that expressed by some respondents included shareholder, business opportunities, high profit and mentor.

Respondents were asked to rank the good traits of entrepreneurs. Result shows most of the respondents agreed that self-confidence is the most important good traits to an entrepreneur (mean=2.8). The other important good traits of entrepreneurs are hard work and energetic (mean $=3.2)$, creative and innovative (mean=3.3) and possess well communication skills $($ mean=3.4). Determined (mean=3.8) and discipline (mean=4.3) are the least 
important good traits ranked by the respondents besides other good traits that are not listed. Respondents were then required to rank the important area in entrepreneurship education. Results show that most of the respondents ranked the creation and innovation (mean=2.8) are the most important area that need to be focused in entrepreneurship education. The other important areas that ranked by the respondents in ascending order are opportunities identification (mean=3.1), communication skills (mean=3.2), business plan development (mean=3.4), risk assessment (mean=3.9) and selling ideas and find customers (mean=4.6).

\subsection{Entrepreneurship Education in UniMAP}

This section describes the analysis and results that gathered regarding the entrepreneurship education in UniMAP. Respondents were required to rate the performance of entrepreneurship education offered in UniMAP. Majority of respondents $(59.2 \%)$ rated the overall performance of entrepreneurship education in UniMAP as good while $10.8 \%$ of respondents rated it as excellent. There are $25.8 \%$ of respondents said that the entrepreneurship education in UniMAP is fair. Only few respondents (4.2\%) rated that the overall performance of entrepreneurship program in UniMAP as poor.

Respondents are required to choose one or more teaching methods that were used in entrepreneurship education in UniMAP. The most common teaching method that was used in delivering entrepreneurship subject is lectures (76.7\%). However, case study $(60.8 \%)$ and practical $(60 \%)$ are often used to deliver the entrepreneurship knowledge and skills as well. The rest of the teaching methods are guest speaker (55\%), interviewing entrepreneurs (41.7\%), business simulation (36.7\%), role player $(25.0 \%)$ and Multimedia exercise (15.8\%). Respondents selected three highest preferred teaching methods which are practical (67.5\%), lectures (53.3\%) and business simulation (50\%). Although the interactive teaching methods have been applied in entrepreneurship education yet the regularity still remain low. UniMAP should increase the regularity of these teaching methods in delivering entrepreneurship education as traditional teaching methods might not able to teach some of the entrepreneurship knowledge and skills to the students (Klein, 2006).

Respondents were then requested to choose one or more assessment methods that were used in entrepreneurship subject in UniMAP. The most frequently used assessment method in UniMAP is written exams $(97.5 \%)$ while the second frequently used assessment method is group project (83.3\%). The other assessments that were used in UniMAP include writing business plan (77.5\%), individual project (60\%), oral presentation (63.3\%), practical $(53.3 \%)$ and essay $(30 \%)$. The three preferred assessment methods chose by respondents are group project (73.3\%), practical (64.2\%) and writing business plan (52.5\%).

Respondents are required to indicate the skills that they desired to learn from entrepreneurship education as well as skills that they acquired during their learning process. The desired skills of respondents in ascending order are problem solving skills $(71.67 \%)$, leadership $(68.33 \%)$, business planning $(67.5 \%)$ presentation and marketing (62.5\%), negotiation $(59.2 \%)$, idea generation $(57.5 \%)$, time management $(44.2 \%)$ and intellectual property management $(41 \%)$. For the acquired skills in ascending order are leadership (65.8\%), presentation and marketing $(64.2 \%)$, idea generation $(60.8 \%)$, business planning $(59.2 \%)$, problem solving skills $(57.5 \%)$, negotiation (47.5\%), time management $(45 \%)$ and intellectual property management $(7.5 \%)$.

\section{Recommendations}

Based on these findings, it is recommended that UniMAP need to increase the consistency of other teaching methods such as business simulation and involvement in business activities beside lectures. This is because some of the entrepreneurship knowledge and skills cannot be gained through traditional teaching methods. Only the interactive teaching methods are able to develop these knowledge and skills. Example, leadership cannot be learned by reading from books or writing exam but only through real time practical in business activities and other interactive methods (Klein, 2006). Hence, UniMAP have to increase the innovative teaching methods in order to teach their students about entrepreneurship knowledge and skills effectively.

The effectiveness of entrepreneurship programs is determined by its strong influence to involve in entrepreneurs activities. Therefore, UniMAP need to organized more entrepreneurship activities to influence the students to involve in business activities. Through the exposure in business activities, the students will be influenced and motivated to engage more in entrepreneurship education. There is also a need to increase the entrepreneurship subject for entrepreneurship education in UniMAP also. Some knowledge such as intellectual property management are desired by students yet there are no related subject is provided. Thus, introduction of new entrepreneurship subjects are needed to expand the entrepreneurship education in UniMAP. More facilities need to be prepared for entrepreneurship education as the current facilities unable to handle the additional improvement. As mention earlier, various studies about entrepreneurship education had been conducted and they suggested that investment in entrepreneurship education can bring huge benefit to the economy and society. This 
study focuses on the entrepreneurship education in UniMAP only. Hence, a more comprehensive research of entrepreneurship education in the context of Malaysia need to be carried out to examine the overall performance of entrepreneurship education in Malaysia. Future study on the intentions of engineering students in UniMAP to be involved in business activities could be carried out to examine the reasons and factors that influence them to take part in business activities. Additional research about the relationship between the traditional teaching methods and interactive teaching methods and their impact toward the entrepreneurship education in UniMAP also need to be investigated. This is because the different teaching methods will have different feedback when it was applied in entrepreneurship education.

\section{Conclusion}

This study provides an important exploratory analysis for entrepreneurship education. An entrepreneurship education should not only provide theoretical knowledge but also able to assist their students on establishing an entrepreneurship mindset through developing entrepreneurial skills, behaviors and attitudes, and train them with entrepreneurial abilities to support them to start their own business venture or engage in entrepreneurship activities. The result shows the entrepreneurship education in the higher learning institution is performing well and there were positive perception from the students toward the entrepreneurship education. Although the entrepreneurship education in this university is still new and recently established, yet the teaching methods and the assessment methods are to be able to reach students expectation. Since there are so many benefits of entrepreneurship education, this university should not be contented with the current performance by now and need to be keep on improving their entrepreneurship education. This study only examines the entrepreneurship education in UniMAP but not the effectiveness of the entrepreneurship education. To study about effectiveness of entrepreneurship education, the involvement of the undergraduate student and post graduate students from UniMAP will be needed. As the School of Business Innovation and Technopreneurship had just been establish for less than three years with only one batch of post graduate students, thus it is very hard to examine the effectiveness as the population are low. More time is needed to determine the effectiveness of entrepreneurship education in UniMAP. Although the time given was two semesters, yet the overloaded assignments from other subjects has limit the time spent in this study. Therefore, more free time had to be given to students who are doing their final year project and reduce the subjects that they need to take in the last two semesters. More time is needed to ensure that students can have full concentration on their final year project and not distracted by other elements such as burden of assignments.

\section{References}

Abduh, M. (2012). A Case Study of Bengkulu University. An Evaluation of the Entrepreneurship Education in Indonesia, 871-882. Retrieved from http://www.ijoi-online.org/attachments/article/30/FINAL\%20ISSUE\% 20VOL\%204\%20NUM\%204\%20SPRING\%202012.pdf

Accelerating Campus Entrepreneurship Initiative Development Committee. (2009). Entrepreneurship Education in Ireland. National Council for Graduate Entrepreneurship. Retrieved from http://www.cit.ie/contentfiles/File/entrepreneurship\%20education\%20in\%20ireland\%20research\%20report2 .pdf?uid=1272470117769

Adcroft, A., Dhaliwal, S., \& Willis, R. (2005). Insatiable demand or academic supply: the intellectual context of entrepreneurship education. European Business Review, 17(6), 518-531. Retrieved from http://epubs.surrey.ac.uk/146743/3/1\%20Insatiable\%20Demand\%20-\%20European\%20Business\%20Revie w\%20Author.pdf

Bosma, N., \& Levie, J. (2010). 2009 Executive Report. Global Entrepreneurship Research Association (GERA). Retrieved from http://www.gemconsortium.org/docs/download/666

Chan, E. S. (2005). Entrepreneurship education in Australia-A Preliminary Study. Journal of Asia $\begin{array}{lllll}\text { Entrepreneurship and } & \text { Sustainbility, } & \text { Retrieved }\end{array}$ http://www.asiaentrepreneurshipjournal.com/vollissueII/chan.pdf

Chaudhary, C. M. (1991). Research Methodology. Jaipur: R B S A Publishers.

Cheng, M. Y., Chan, W. S., \& Mahmood, A. (2009). The effectiveness of entrepreneurship education in Malaysia. Education + Training, 51(7), 555-566. http://dx.doi.org/10.1108/00400910910992754

Felder, R. M., \& Brent, R. (2005). Understanding Student Different. Journal of Engineering Education, 57-72. Retrieved from http://files.eric.ed.gov/fulltext/ED244959.pdf

Garavan, T. N., \& O'Cinneide, B. (1994). Entrepreneurship education and Training Programmes: A Review and 
Evaluation Part 1. Journal of European Industrial Training, 18(8), 309-590. Retrieved from http://www.emeraldinsight.com/doi/abs/10.1108/03090599410068024

Gartner, W. B. (1985). A Conceptual Framework for Describing the Phenomenon of New Venture Creation. The Academy of Management Review, 696-706. http://dx.doi.org/10.5465/AMR.1985.4279094

Gibb, A. (1993). The Enterprise Culture and Education: Understanding Enterprise Education and its Links with Small Business Entrepreneurship and Wider Education Goals. International Small Business Management, 11(3). http://dx.doi.org/10.1177/026624269301100301

Gorman, G., Hanlon, D., \& King, W. (1997). Some research perspectives on entrepreneurship education, enterprise education and education for small business management: A ten-year literature review. International Small Business Journal, 56-78. Retrieved from http://mgmt.iisc.ernet.in/ piyer/Entrepreneurship_Management/Some\%20Research\%20Perspectives\%20On \%20Entrepreneurship\%20Education\%201997\%20v15(3)\%20p56.pdf

Hisrich, R. D., Michael, P. P., \& Shephard, D. A. (2005). Entrepreneurship. New York: McGraw-Hill Irwin.

Importance of Entrepreneurship Education. (2004). National Content Standards. Retrieved from http://www.entre-ed.org/Standards_Toolkit/importance.htm

Jones, C., \& English, J. (2004). A contemporary approach to entrepreneurship. Education\&Training, 46(89), 416-423. Retrieved from http://www.emeraldinsight.com/doi/abs/10.1108/00400910410569533

Katz, J. (2003). The Chronology and Intellectual Trajectory of American Entrepreneurship Education 1876-1999. Journal of Business Venturing, 18(2), 283-300. Retrieved from http://olim.org/wiki/uploads/Articles/Katz2003HistoryEntrepreneurshipEducation.pdf

Kirby, D. A. (2002). Didactical and entrepreneurial models of learning. National Council for Small Business (p. 24). San Juan. Retrieved from http://www.yedac.eu/media/2765/YEDAC-Entrepreneurial-education-Joint -article-1-.pdf

Klein, P. G. (2006). Can Entrepreneurship be Taught? Journal of Agricultural and Applied Economics. Retrieved from https://mospace.library.umsystem.edu/xmlui/bitstream/handle/10355/137/Can\%20Entrepreneurship\% 20be $\% 20$ Taught.pdf? sequence $=1$

Kuratko, D. F. (2004). Entrepreneurship education in the 21st Century: From Legitimization to Leadership. USASBE National Conference (p. 16). Muncie. Retrieved from http://faculty.bus.olemiss.edu/dhawley/ PMBA622\%20SP07/Sloan/L3_M11_Entre_Education.pdf

Kuratko, D. F. (2005). The Emergence of Entrepreneurship Education: Development, Trends. and Challenges. Entrepreneurship: Theory and Practice, 29, 577-597. Retrieved from https://entrepreneurship.okstate.edu/ files/The_Emergence_of_Entrepreneurship_Education_Development_Trends_and_Challenges.pdf

Lekoko, M., Rankhumise, E. M., \& Ras, P. (2012). The effectiveness of entrepreneurship education: What matter most? African Journal of Business Management, 6(51), 12023-12033. Retrieved from http://www.academicjournals.org/article/article1380814071_Lekoko\%20et\%20al.pdf

Lewin, P. (2002). Entrepreneurship and the Defense of Capitalism: An Examination of the Work of Israel Kirzner. Journal des Economistes et des Etudes Humaines, 12(2), Article 2. http://dx.doi.org/10.2202/1145-6396.1057

Lybaert, N. (1998). The Information Use in a SME: Its Importance and Some Elements of Influence. Small Business Economics, 10, 171-191. http://dx.doi.org/10.1023/A:1007967721235

Ma, H., \& Tan, J. (2006). Key Components and implications of entrepreneurship: A 4-P framework. Journal of Business Venturing, 21, 704-725. Retrieved from http://www.sciencedirect.com/science/article/pii/ S0883902605000522

Makip, M. R. (2012). SME Developement in Malaysia. MIA Conference 2012-Merger \& Affiliation Seminar (p. 29). Kuala Lumpur: SME Corporation Malaysia. Retrieved from http://www.mia.org.my/at/at/2012/10/ 05.pdf

McNabb, D. E. (2008). Research Methods in Public Administration and Nonprofit Management. New York: M.E. Sharpe.

Praag, C. M. (1999). Some Classic Views on Entrepreneurship. De Economist, 147(3), 311-335. http://dx.doi.org/10.1023/A:1003749128457 
Solomon, G. (2007). An examination of entrepreneurship education in United States. Journal of Small Business and Enterprise Development, 14(2), 168-182. http://dx.doi.org/10.1108/14626000710746637

Souitaris, V., Zerbinati, S., \& Al-Laham, A. (2007). Do entrepreneurship programmes raise entrepreneurial intention of science and engineering student? The effect of learning, inspiration and resources. Journal of Business Venturing, 22, 566-591. Retrieved from http://www.researchgate.net/profile/Vangelis_Souitaris/publication/4968103_Do_entrepreneurship_program mes_raise_entrepreneurial_intention_of_science_and_engineering_students_The_effect_of_learning_inspir ation and resources/links/00463522724582a091000000

Tan, S. S., \& Ng, C. K. F. (2006). A problem-based learning approach to entrepreneurship education. Education + Training, 48, 416-428. http://dx.doi.org/10.1108/00400910610692606

Varela, R., \& Romero, A. C. M. (2009). Effectiveness of an Entrepreneurial Education Program, 17.

\section{Copyrights}

Copyright for this article is retained by the author(s), with first publication rights granted to the journal.

This is an open-access article distributed under the terms and conditions of the Creative Commons Attribution license (http://creativecommons.org/licenses/by/3.0/). 